\title{
TEACHING AND LEARNING DIFFICULTIES AMONG TEACHERS AND INTELLECTUAL HANDICAPPED CHILDREN IN TEACHING CLASS ROOMS IN MANSOURA CITY
}

\author{
Prof. Dr . Enas Helmy Elshair¹, Assistant prof. Maha Moussa Mohamed Moussa ${ }^{2}$, \\ Dr. Afaf Abdallah Mohammed Mossad ${ }^{3}$, Heba Elsaid Mohammed Elsaid El-Emam ${ }^{4}$ \\ Prof of Community Health Nursing Faculty of Nursing - Cairo University ${ }^{l}$, Assistant prof of Family \\ and Community Health Nursing, Faculty of Nursing - Port Said University ${ }^{2}$, Lecturer of Family and \\ Community Health Nursing, Faculty of Nursing - Port Said University ${ }^{3}$, B.Sc Nursing, Cairo \\ University $2006^{4}$.
}

\begin{abstract}
Background: Intellectual disability is a term which is used when a person has certain limitations in mental functioning and skills such as communication, daily living activities and social skills. Objectives: The aim of this study was to assess teaching and learning difficulties among teachers and intellectual handicapped children in teaching classrooms in Mansoura city. Subjects and Method: Design : A descriptive research design was utilized in this study. Setting: The study was carried out in five intellectual schools in Mansoura city. Sample: A simple random sample for both students and teachers was taken. Subjects Was (273 students and 150 teachers) from the previous study settings. Tools:- Two tools were used on this study: First tool assessment of burnout and psychological exhaustion for special education teachers and second tool is measurement of psychological combustion adaptation patterns of caregivers of children with intellectual disabilities. Results: The study results revealed that $65.3 \%$ of teachers faced difficulties during teaching process because frequent absence of students. $71.1 \%$ of children were partially dependent on family in daily living activities. There was no statistically significant relation between years of experience of the teacher and the difficulties that faced them. Conclusion: The majority of the teachers faced difficulties during teaching and the majority of the studied children had mild degree of disability. Recommendations: It was recommended that training courses should be provided to the teachers to update their information about methods of teaching the handicapped children and for caregivers to improve the health status of their children.
\end{abstract}

Key words: Intellectual disability, Teaching and learning difficulties, Teachers of handicapped children, Mansoura city 


\section{INTRODUCTION}

Intellectual handicapped is a complex disorder it is a term used when a person has certain limitations in mental functioning and skills including communication, daily living activity and social skills. These limitations will cause a child to learn and develop more slowly than normal child. Children with intellectual handicapping may take longer to learn speaking, walking and take care of their personal needs such as dressing and eating (American Association of Mental Retardation, 2015).

Most common causes of intellectual handicapped are genetic conditions, problems during pregnancy. A woman who drinks alcohol or gets an infection like rubella during pregnancy may also have a baby with intellectual disability. Problems at birth or during labor, diseases like whooping cough, measles or meningitis can cause an intellectual disability. Intellectual disabilities can also be caused by extreme malnutrition, not getting enough medical care or by being exposed to poisons like lead or mercury (Donna, Flavo \& Ballard, 2013).

Intellectual handicapped include mild, moderate, sever and profound, Mild degree of handicapped capable of profiting from elementary schooling and achieve sufficient levels of social and vocational skills with moderate developmental milestones like sitting, standing, walking, talking are delayed. Moderate handicapped characterized by the ability to profit from ordinary education and vocational training. Severe handicapped show serious motor, speech and behavioral impairment (McKenzie, Milton, Smith \& Ouellette-Kuntz, 2016).

The purpose of special education is to provide individualized instruction to meet the needs of the heterogeneous group of students with disabilities. Meeting the needs of this group of students is extremely challenging and requires teachers who are highly skillful. Unfortunately, student with disability are more often served by the special education teaching force that is highly subject to attrition and turnover, which compromises the educational services that they receive (Alexander, 2014).

Community Health Nurses $(\mathrm{CHN})$ frequently provides direct patient care for vulnerable and underserved populations. Workforce supply and worker characteristics, such as educational background, continue to be important considerations when assessing the capacity of the CHN workforce to effectively deliver public health services (Beck \& Boulton, 2016). Community health nursing interventions are nursing activities that promote mental health, prevent mental illness, 
assess dysfunction, and assist clients to regain, improve the coping abilities and prevent further disabilities (Ahmed, 2010).

\section{AIM OF STUDY:}

The aim of this study was to assess the teaching and learning difficulties among teachers and intellectual handicapped children in teaching classrooms.

\section{Research Questions:}

1. What are the types of teaching difficulties that facing the teacher?

2. What are the types of learning difficulties that facing the intellectual handicapped children?

3. What are the learning and teaching needs of intellectual handicapped children?

\section{SUBJECTS AND METHOD:}

- Study Design: A descriptive exploratory study design was used.

- Settings: The study was conducted at five intellectual education schools in Mansoura city namely (El- Mansoura, Dekernes, Meniat Elnaser, Elreyad and Sherbeen).

- Subjects: the sample consisted of 150 teachers' males and females who were working at the previous mentioned study settings. And 273 children males and females from the previous mentioned study settings.

\section{Tools for data collection:}

\section{Tool for the teachers}

\section{Burnout and psychological exhaustion questionnaire:}

It is a questionnaire adopted from (Rady, 1999). It has been used to assess sociodemographic characteristics and professional skills for the teachers. The aim of this tool was to assess difficulties that facing special education teachers during teaching process. The tool consists of two parts.

Part 1: It consisted of three items:

- Socio-demographic data: for the teacher such as: age, sex, the qualifications, and years of experience, etc, it include 6 questions.

- Factors effect on teaching strategies such as: right environment for the education of the children .etc, it include 6 questions.

- Difficulties that facing teachers during teaching process such as: frequent absences of the students, different in thinking capacity etc, it include 8 questions. 
Part 2: Observational check list for the teacher. The aim was to observe methods of teaching followed by the teacher in the teaching classroom, such as: the teacher used teaching aids eg (computer, drawing, data show, role play, lecture,..........etc, it include 7 questions.

Scoring system in observational checklist the response of teachers if yes mean (1) score and if no mean (0) score.

Tool for intellectual handicapped children

psychological combustion and adaptation of patterns with intellectual disabilities children.

The aim was to assess teaching and learning difficulties among intellectual handicapped children in teaching classrooms. This tool was adopted from Waziry (2002).

Part 1: it consists of three items:

- Socio-demographic data for the children such as; name of child, age, sex ...etc (it include 10 questions).

- $\quad$ Past history of intellectual disability child; degree of disability IQ, times for discovery of disability, causes of disability, ....etc, it include 9 questions.

- School achievement, social and emotional support of child such as; have a special computer, the child has a financial additional requirement...etc, it includes 11 questions.

Scoring System To determine the degree of dependency of studied children in ADLs the following scoring is done: for each skill question a score $=0$ if completely dependent, $1=$ partially dependent and 2 if done independent. Then the score of the aspects of the skill are added and a percent is calculated. e.g., activity of daily living included 10 questions with a maximum score of 20 , if a child scored 5 this is transformed into $25 \%=(20 / 4)$. This will help to identify the best and worst skill.

\section{Part 2:}

Observational check list for the children. The aim was to assess activities of intellectual handicapped children in classrooms, such as: participate in daily activity, he/she plays with their friends in the classroom...... etc, it include 10 questions.

Scoring system of Likert scale for participation activities: items were scored 2, 1 , and 0 for the responses always, sometimes, and rarely respectively. The scores of the items were summed-up and the total divided by the number of the items, giving a mean score for the part. These scores were converted into a percent score. The children activities were considered positive if the percent score was $60 \%$ or more, and negative if it less than $60 \%$. 


\section{Validity of the tools:}

The tools were checked by five experts in the field of Family and Community Health Nursing department and Educational Psychology department. Modification based on the expert's opinions was done.

\section{Reliability of the tools:}

Cronbach alpha coefficient was calculated to assess the reliability of the tool through their internal consistency. Principle component analysis of all questionnaires indicated that all had good construct validity as they clearly measured one construct. The questionnaires were deemed reliable based on the results of Cronbach alpha coefficient 0.87 .

\section{Pilot Study:}

About $10 \%$ of total of the study samples, which include (15 teachers and 25 child) three teachers from each school and five children from each school. The pilot study was carried out before data collection to assess the content validity, clarity of the tools and estimated the time needed to complete the tool for teacher (Part 1: demographic data taken 10 minutes and part 2 observation sheet taken 30 minutes). The tool for children (Part 1: demographic data taken 30 minutes and part 2 observation activity sheet taken 30 minutes). The schools were visited 3 days per week for 3 hours per each times. Modifications were done according to the results of the pilot study. The pilot study subjects were excluded from the total study sample.

\section{ADMINISTRATIVE DESIGN:}

An official permission was obtained from both the Dean of the Faculty of Nursing, Port Said University, the directors of the schools and teachers of each selected school before conducting the study.

\section{Ethical Consideration:}

The approval was taken from Ethical Consideration Committee in Faculty of Nursing Port Said University. The aim of the study was explained to the directors of the intellectual educational schools to take their permission to carry this study. Permission of the teachers to participate after explaining the aim of the study. Permission of the caregivers to participate after explaining the aim of the study. A brief explanation of the study given to assure the confidentiality of the information gathered that was used for the purpose of the study. 


\section{Field work:}

The study was conducted during the period from September 2014 to May 2015. The schools were visited 3 to 4 days per week at (Sunday, Monday, Tuesday and Wednesday) for 4 hours per each visit. The data were collected from teacher and caregivers along 9 months as the following:

\begin{tabular}{|l|l|l|l|}
\hline \multirow{2}{*}{ School name } & $\begin{array}{l}\text { Number of } \\
\text { teachers }\end{array}$ & $\begin{array}{l}\text { Number of visit } \\
\text { per week }\end{array}$ & $\begin{array}{l}\text { Number of days per } \\
\text { school }\end{array}$ \\
\cline { 2 - 5 } & 38 & 3 & 13 \\
\hline Dekernas & 32 & 3 & 11 \\
\hline Meneaelnasr & 25 & 3 & 8 \\
\hline Alreyad & 25 & 3 & 8 \\
\hline Sherbeen & 30 & 3 & 10 \\
\hline Total & 150 & 15 & 50 about (4 months and 1 \\
& & & week \\
\hline
\end{tabular}

The sample of studies was (150) teachers and (273) intellectual handicapped children from 5 intellectual schools, each school was visited describe in this table.

\section{For the teachers}

Each teacher was interviewed to collect data from 10-15 minutes to fill in questionnaire. The data was collected from the teachers at the teachers' room from September to December 2014. The research investigator met three teachers per times. Then enter three classes with them and took about 30 minutes to complete the observation check list for the teachers. The settings were visited 3 days per week at Sunday, Monday and Tuesday.

\section{For the intellectual handicapped children}

The data was collected from the children through asking caregivers questions during waiting their children at the garden of the school from November to end of January 2015 to May 2015. The research investigator met four caregivers per times the caregiver took about 20-30 minutes to fill in the form. Then the researcher observed the activity of the child at the classroom and took about 30 minutes. About eight to ten children per each 
class. The settings were visited 4 days per week at (Sunday, Monday, Tuesday and Wednesday).

\section{STATISTICAL ANALYSIS:}

The collected data were organized, coded, transferred into especially designed formats and then statistically analyzed using Statistical Package of Social Science (SPSS) program version 20. The data were tabulated and presented. Statistical descriptive measures as number, percentage, mean and Standard Deviation (mean \pm SD) for quantitative data were used.

Appropriate statistical tests were used as: Chi- square $\left(\chi^{2}\right)$ test, Fisher Exact (FE) test, and Monte Carlo (MC) test. The difference in this study was considered statistically significant at $\mathrm{p}$ value $\leq 0.05$.

\section{RESULTS:}

Distribution of studied teachers according to their demographic characteristics table (1) Represent that $80.0 \%$ of the teachers aged above 40 years, and $60.7 \%$ of them were females. As well, $66.7 \%$ of the teachers had bachelor degree in special education, and $62.7 \%$ of them had more than 15 years of experience. and $96.7 \%$ of them had previous training course in how to deal with intellectual handicapped children.

Distribution of factors that affecting educational program at the schools Table (2) Shows that $96.7 \%$ of the teachers were using teaching aids. about $70.0 \%$ of teachers used booklets and $93.3 \%$ of the teachers agree that the schools create the right climate for education while $56.7 \%$ of teachers' opinion that the curriculum commensurate with the capabilities of the children.

Distribution of difficulties that facing the teachers during teaching the intellectual handicapped students in figure (1) Indicated that $65.3 \%$ of the difficulties were related to frequent absence of students. $58.0 \%$ of the difficulties were due to the differences in thinking capacity of children. In addition about $52.0 \%$ of the difficulties were related to lack of understanding of parents to the nature of teaching in these schools. While, $11.3 \%$ of these difficulties were due to acceptance of unsuitable students to attend to school. 
Table (3): Illustrates the methods of teaching. It shows that $93.3 \%$ of teachers used the teaching aids in the commentary. $75.3 \%$ of teachers used group discussion through shared answer with students and $86.7 \%$ of them encourage child to participate through gifts. While $70.0 \%$ of teachers used manual skills to develop skills of the child and $90.7 \%$ of teachers were keen to use various methods of communication.

Table (4): presents the past history of the diseases of the children. It shows that about $54.2 \%$ of them had mental disability from (50-70degree). $33.0 \%$ of children were affected by hereditary. $46.7 \%$ of them were cousin. While, about $65.2 \%$ of them the disability was discovered at birth. $49.8 \%$ of the study sample had a genetic factor as a cause of disability.

Table (5): Represents the relation between methods of teaching in classrooms and qualifications of teachers. It indicates that there was a statistically significant relation between qualification of teachers and drawing skills of the child $(\mathrm{p}=0.005)$.

Table (6): Illustrate the relation between difficulties that facing teachers and years of experience of them. It shows that there were no statistically significant relations between the types of difficulties that facing them during teaching process and years of experience of the teachers ( $p$-value >0.05). As the frequent absence of the students because of their health status $(\mathrm{p}=0.254)$.

Table (7): Represents the relation between school achievement of the intellectual handicapped child and the degree of mental disability. It shows that there were a statistically significant relations between degree of mental disability and school achievement $(p=0.005)$, helping their sons in studying $(p=0.007)$, the child makes a financial overload $(p=0.016)$ and the child needs additional financial requirement ( $p=0.011$. 
Table (1): Distribution of studied teachers according to their demographic characteristics.

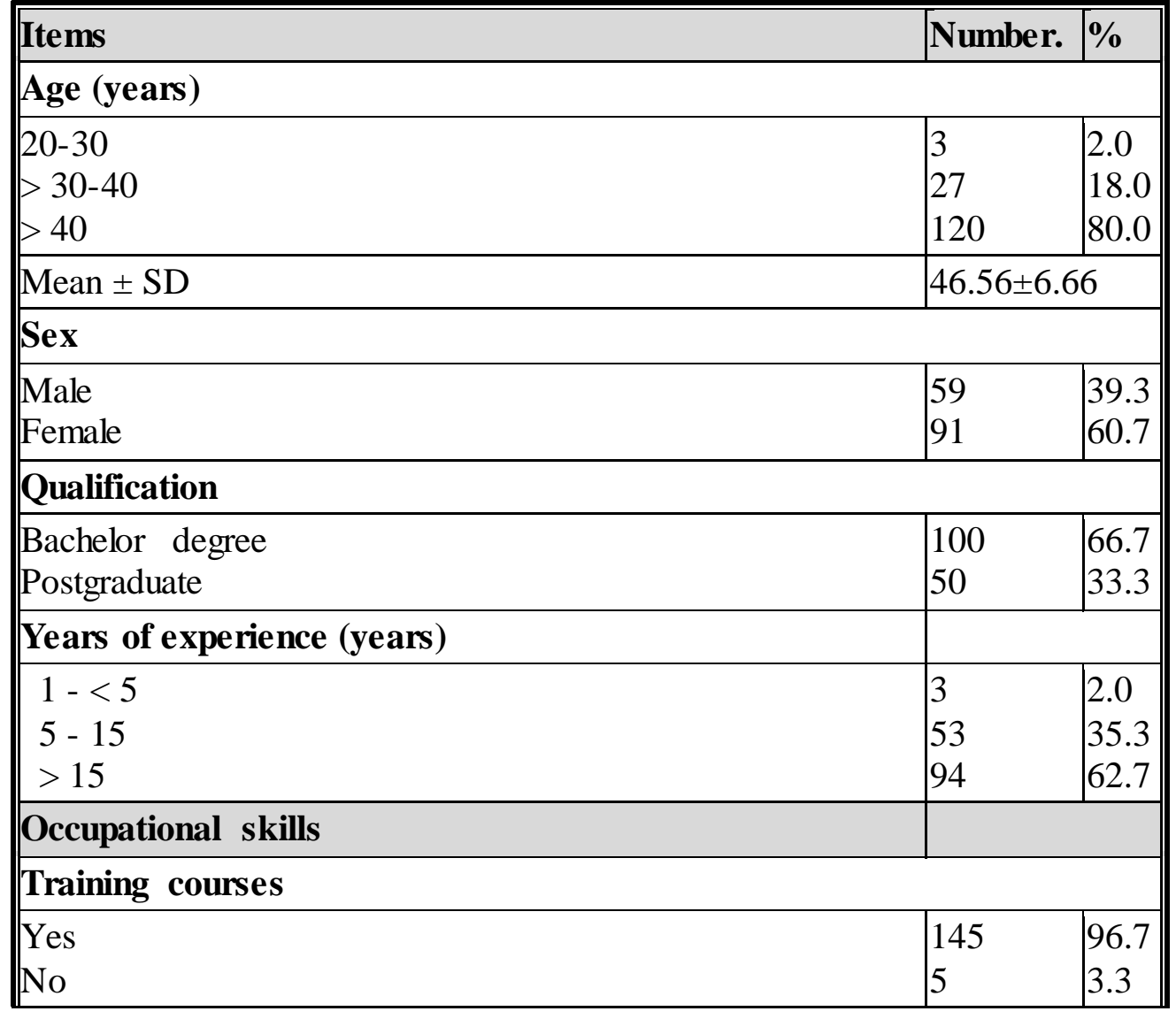

Table (2): Distribution of factors that affecting educational program at the schools

\begin{tabular}{|c|c|c|}
\hline Items & $\begin{array}{l}\text { Numbe } \\
\text { r. }\end{array}$ & $\%$ \\
\hline $\begin{array}{l}\text { School teaching aids } \\
\text { Yes } \\
\text { No }\end{array}$ & $\begin{array}{l}145 \\
5\end{array}$ & $\begin{array}{l}96.7 \\
3.3\end{array}$ \\
\hline \multicolumn{3}{|l|}{ Types of teaching aids (More than one aid were selected) } \\
\hline $\begin{array}{ll}\text { - } & \text { Data show } \\
\text { - } & \text { Educational documents } \\
\text { - } & \text { Booklets } \\
\text { Others }\end{array}$ & $\begin{array}{l}71 \\
95 \\
105 \\
43\end{array}$ & $\begin{array}{l}47.3 \\
63.3 \\
70.0 \\
28.7\end{array}$ \\
\hline $\begin{array}{l}\text { Suitable environment for education } \\
\text { Yes } \\
\text { No }\end{array}$ & $\begin{array}{l}140 \\
10\end{array}$ & $\begin{array}{l}93.3 \\
6.7\end{array}$ \\
\hline $\begin{array}{l}\text { The curriculum commensurate with the capabilities of the } \\
\text { children } \\
\text { Yes } \\
\text { No }\end{array}$ & $\begin{array}{l}85 \\
65\end{array}$ & $\begin{array}{l}56.7 \\
43.3\end{array}$ \\
\hline
\end{tabular}




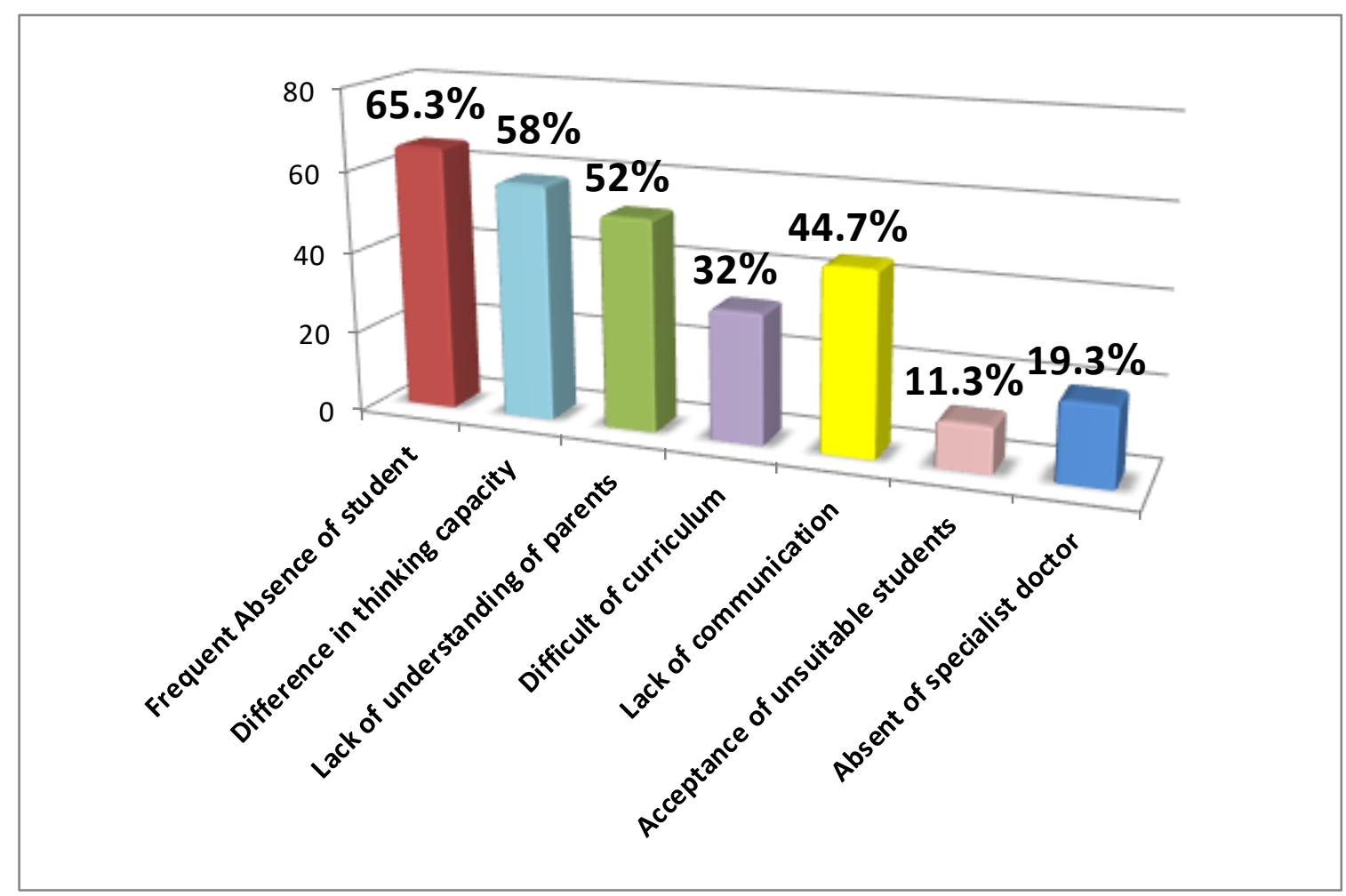

Figure (1): Difficulties that facing the teachers during teaching the intellectual handicapped students

Table (3): Methods of teaching for intellectual handicapped children in teaching classrooms

\begin{tabular}{|c|c|c|c|c|}
\hline \multirow{2}{*}{ Items } & \multicolumn{2}{|l|}{ Yes } & \multicolumn{2}{|l|}{ No } \\
\hline & No. & $\%$ & No. & $\%$ \\
\hline Teaching aids & 140 & 93.3 & 10 & 6.7 \\
\hline Feedback & 82 & 54.7 & 68 & 45.3 \\
\hline \multicolumn{5}{|l|}{ Types of group discussion } \\
\hline - $\quad$ Giving practical activities & 65 & 43.3 & 85 & 56.7 \\
\hline Shared answer with students & 113 & 75.3 & 37 & 24.7 \\
\hline - $\quad$ Others & 12 & 8.0 & 138 & 92.0 \\
\hline \multicolumn{5}{|l|}{ Encourage child to participate through } \\
\hline - $\quad$ Gifts & 130 & 86.7 & 20 & 13.3 \\
\hline Putting his/her name in the panel of honor & 56 & 37.3 & 94 & 62.7 \\
\hline Putting the badge on the chest & 14 & 9.3 & 136 & 90.7 \\
\hline - $\quad$ Others & 18 & 12.0 & 132 & 88.0 \\
\hline \multicolumn{5}{|l|}{ Development the child skills through } \\
\hline - $\quad$ Computer & 59 & 39.3 & 91 & 60.7 \\
\hline Drawing & 100 & 66.7 & 50 & 33.3 \\
\hline Manual skills & 105 & 70.0 & 45 & 30.0 \\
\hline Others & 9 & 6.0 & 141 & 94 \\
\hline Using various methods of communication & 136 & 90.7 & 14 & 9.3 \\
\hline Students participation & 66 & 44.0 & 84 & 56.0 \\
\hline
\end{tabular}


Table (4): Distribution of studied children according to their past history of handicapped

\begin{tabular}{|c|c|c|}
\hline Items & Number & $\%$ \\
\hline \multicolumn{3}{|l|}{ Degree of mental disability } \\
\hline $\begin{array}{l}\text { mild } 50-70 \\
\text { moderate } 35-49 \\
\text { sever } 20-34 \\
\text { profound }<20\end{array}$ & $\begin{array}{l}148 \\
90 \\
33 \\
2\end{array}$ & $\begin{array}{l}54.2 \\
33.0 \\
12.1 \\
0.7\end{array}$ \\
\hline $\begin{array}{l}\text { Hereditary } \\
\text { Yes } \\
\text { No }\end{array}$ & $\begin{array}{l}90 \\
183\end{array}$ & $\begin{array}{l}33.0 \\
67.0\end{array}$ \\
\hline $\begin{array}{l}\text { If yes what is the relation }(\mathrm{n}=90) \\
\text { Cousins } \\
\text { Related to mother } \\
\text { Others }\end{array}$ & $\begin{array}{l}42 \\
25 \\
23\end{array}$ & $\begin{array}{l}46.7 \\
27.8 \\
25.5\end{array}$ \\
\hline $\begin{array}{l}\text { Time for discovery of disability } \\
\text { At the birth } \\
\text { At the vaccination } \\
\text { Others(school age) }\end{array}$ & $\begin{array}{l}178 \\
63 \\
32\end{array}$ & $\begin{array}{l}65.2 \\
23.1 \\
11.7\end{array}$ \\
\hline $\begin{array}{l}\text { Cause of disability } \\
\text { Genetic factor } \\
\text { Medical fault during child birth(iatrogenic) } \\
\text { Medication and drugs during the pregnancy } \\
\text { An accident }\end{array}$ & $\begin{array}{l}136 \\
60 \\
66 \\
11\end{array}$ & $\begin{array}{l}49.8 \\
22.0 \\
24.2 \\
4.0\end{array}$ \\
\hline
\end{tabular}


Table (5): Relation between methods of teaching in classrooms and qualification of teachers

\begin{tabular}{|c|c|c|c|c|c|c|}
\hline \multirow{3}{*}{ Methods of teaching } & \multicolumn{4}{|c|}{ Qualification } & \multirow{3}{*}{ X 2} & \multirow{3}{*}{$\mathbf{P}$} \\
\hline & \multicolumn{2}{|c|}{$\begin{array}{c}\text { Bachelor's degree } \\
(\mathrm{n}=100)\end{array}$} & \multicolumn{2}{|c|}{$\begin{array}{c}\text { Postgraduate } \\
(\mathbf{n}=50)\end{array}$} & & \\
\hline & No. & $\%$ & No. & $\%$ & & \\
\hline \multicolumn{7}{|l|}{ Group discussion } \\
\hline Give practical activities & 44 & 44.0 & 21 & 42.0 & 0.054 & 0.816 \\
\hline $\begin{array}{l}\text { Shared ans wer with } \\
\text { students }\end{array}$ & 75 & 75.0 & 38 & 76.0 & 0.018 & 0.893 \\
\hline Other & 6 & 6.0 & 6 & 12.0 & $\begin{array}{c}\mathrm{FE} \\
1.630\end{array}$ & 0.216 \\
\hline \multicolumn{7}{|l|}{$\begin{array}{l}\text { Develop the child skills in } \\
\text { classrooms } \\
\text { through }\end{array}$} \\
\hline Computer & 35 & 35.0 & 24 & 48.0 & 2.361 & 0.124 \\
\hline Drawing & 59 & 59.0 & 41 & 82.0 & 7.935 & $0.005^{*}$ \\
\hline Manual skills & 75 & 75.0 & 30 & 60.0 & 3.571 & 0.059 \\
\hline
\end{tabular}


Table (6): Relation between difficulties that facing teachers and years of experience of them

\begin{tabular}{|c|c|c|c|c|c|c|c|c|}
\hline \multirow{3}{*}{ Difficulties facing teachers* } & \multicolumn{6}{|c|}{ Years of experience } & \multirow{3}{*}{$X 2$} & \multirow{3}{*}{${ }^{\mathrm{MC}} \mathbf{p}$} \\
\hline & \multicolumn{2}{|c|}{$\begin{array}{l}1-5 \\
(n=3)\end{array}$} & \multicolumn{2}{|c|}{$\begin{array}{l}5-15 \\
(n=53)\end{array}$} & \multicolumn{2}{|c|}{$\begin{array}{l}>15 \\
(n=94)\end{array}$} & & \\
\hline & No. & $\%$ & No. & $\%$ & No. & $\%$ & & \\
\hline $\begin{array}{l}\text { The frequent absence of the } \\
\text { students because of their } \\
\text { health status }\end{array}$ & 1 & 33.3 & 38 & 71.7 & 59 & 62.8 & 2.626 & 0.254 \\
\hline $\begin{array}{l}\text { Difference in thinking } \\
\text { capacity and the lack of } \\
\text { interaction with the teacher }\end{array}$ & 1 & 33.3 & 33 & 62.3 & 53 & 56.4 & 1.324 & 0.576 \\
\hline $\begin{array}{l}\text { Lack of understanding of } \\
\text { parents to the nature of } \\
\text { teaching in these schools }\end{array}$ & 1 & 33.3 & 31 & 58.5 & 46 & 48.9 & 1.737 & 0.449 \\
\hline $\begin{array}{l}\text { The difficulty of the } \\
\text { curriculum and lack of } \\
\text { suitability for the } \\
\text { capabilities of these children }\end{array}$ & 1 & 33.3 & 18 & 34.0 & 29 & 30.9 & 0.387 & 0.869 \\
\hline $\begin{array}{l}\text { The lack of communication } \\
\text { specialists in the school }\end{array}$ & 0 & 0.0 & 19 & 35.8 & 48 & 51.1 & 5.208 & 0.054 \\
\hline $\begin{array}{l}\text { Acceptance of unsuitable } \\
\text { students to attend to school }\end{array}$ & $\mathbf{0}$ & 0.0 & 4 & 7.5 & 13 & 13.8 & & \\
\hline $\begin{array}{l}\text { The absence of specialist } \\
\text { doctor on school }\end{array}$ & 0 & 0.0 & 10 & 18.9 & 19 & 20.2 & 0.300 & 1.000 \\
\hline All the above & 2 & 66.7 & 15 & 28.3 & 27 & 28.7 & 2.066 & 0.360 \\
\hline
\end{tabular}


Table (7): Relation between students' school achievement and degree of mental disability

\begin{tabular}{|c|c|c|c|c|c|c|c|c|c|c|}
\hline \multirow{3}{*}{ School achievement } & \multicolumn{8}{|c|}{ Degree of mental disability } & \multirow{3}{*}{$\mathbf{X} 2$} & \multirow{3}{*}{${ }^{\mathrm{MC}} \mathbf{p}$} \\
\hline & \multicolumn{2}{|c|}{$\begin{array}{l}(50: 70) \\
(n=148)\end{array}$} & \multicolumn{2}{|c|}{$\left(\begin{array}{l}(35: 50) \\
(\mathbf{n}=90)\end{array}\right.$} & \multicolumn{2}{|c|}{$\left(\begin{array}{l}(20: 35) \\
(n=33)\end{array}\right.$} & \multicolumn{2}{|c|}{$\begin{array}{l}(<20) \\
(n=2)\end{array}$} & & \\
\hline & No. & $\%$ & No. & $\%$ & No. & $\%$ & No. & $\%$ & & \\
\hline $\begin{array}{l}\text { School achievement } \\
\text { Acceptable success }\end{array}$ & 36 & 24.3 & 14 & 15.6 & 4 & 12.1 & 1 & $\mathbf{5 0 . 0}$ & & \\
\hline Moderate success & 100 & 67.6 & 57 & 63.3 & 19 & 57.6 & 1 & 50.0 & 16.916 & $0.005^{*}$ \\
\hline Doesn't achieve any success & 12 & 8.1 & 19 & 21.1 & 10 & 30.3 & $\mathbf{0}$ & 0.0 & & \\
\hline $\begin{array}{l}\text { Help their son in studying } \\
\text { Rarely }\end{array}$ & 37 & 25.0 & 37 & 41.1 & 14 & 42.4 & 0 & $\mathbf{0 . 0}$ & & \\
\hline Sometimes & 89 & 60.1 & 37 & 41.1 & 18 & 54.5 & 1 & 50.0 & 15.993 & $0.007^{*}$ \\
\hline Always & 22 & 14.9 & 16 & 17.8 & 1 & 3.0 & 1 & 50.0 & & \\
\hline $\begin{array}{l}\text { Child make financial ove } \\
\text { load of the family }\end{array}$ & & & & & & & & & & \\
\hline Yes & 92 & 62.2 & 63 & 70.0 & 29 & 87.9 & 2 & 100.0 & 9.449 & $0.016^{*}$ \\
\hline No & 56 & 37.8 & 27 & 30.0 & 4 & 12.1 & $\mathbf{0}$ & 0.0 & & \\
\hline $\begin{array}{llr}\text { Child } & \text { need additiona } \\
\text { financial } & \text { requirement } & \\
& & \\
\text { other peers } \\
\text { Yes } \\
\text { No } & & \\
\text { Nor }\end{array}$ & $\mid \begin{array}{l}90 \\
58\end{array}$ & $\begin{array}{l}60.8 \\
39.2\end{array}$ & 59 & $\begin{array}{l}65.6 \\
34.4\end{array}$ & 29 & $\begin{array}{l}87.9 \\
12.1\end{array}$ & $\begin{array}{l}2 \\
0\end{array}$ & $\begin{array}{l}100.0 \\
0.0\end{array} \mid$ & 10.092 & $0.011^{*}$ \\
\hline
\end{tabular}

$\chi^{2}, p: \chi^{2}$ and $p$ values for Chi square test

MC: Monte Carlo for Chi square test

*: Statistically significant at $p \leq 0.05$

DISCUSSION:

Intellectual handicapped is not easily cured as other physical disorders and it requires long treatment course and close supervision. Students with learning problems tend to be passive learners. Because of their history of difficulty with learning which defined as a disorder in one or more of the basic psychological processes involved understanding, using language, spoken and written. While Teaching difficulties' refers to the problems 
faced the teacher during teaching process as weak perception of handicapped children, slow or absence of progress of children.

The present study aimed to assess the teaching and learning difficulties among teachers and intellectual handicapped children. The study carried out on 150 teachers and 273 students selected from 5 intellectual schools.

According to the age of the teachers the present study revealed that the majority of teachers were aged above 40 years. This result may be due to there is no new recruitment in the government for the special education teachers. This result is agreed with Vas et al, (2015) who stated that $63.4 \%$ of teachers had aged ranged from (35 to 55) years. The study was done in Western Australia which it discussed the "Factors Associated with Primary School Teachers' Attitudes towards the Inclusion of Students with 'Disabilities”.

The result of the present study revealed that more than half of the special education teachers had years of experience more than 15 years. This result may be due to the majority of the teachers had aged above 40 years and they were worked from a long time. In contradiction with these findings Hamden et al. (2016); Vas et al, (2015) have found that about $47.1 \%$ of teachers had years of experience ranged from (1 to 8) years. This result presented in the "implementation of co-teaching approach in an inclusive classroom: overview of the challenges, readiness and role of special education teacher in Malaysia (Asia)".

Concerning the teaching aids, the present study revealed that almost of teachers used teaching aids during teaching process in the special education classrooms and the majority of them used booklet. These results may be due the teachers claimed to facilitate the teaching process and to help them to delver the information to the students in a simple way. This result is congruent with the result of Boujut, Dean, Grouselle, and Cappe (2016) who have emphasized that the majority of the teachers used teaching aids in teaching classrooms. This result found in "Comparative Study of Teachers in Regular Schools and Teachers in Specialized Schools in France."

According to the difficulties that facing the teachers, the present study showed that one third of the teachers illustrated that the curriculum was difficult and there was a lack 
of suitability for the capabilities of these children. This results may be due to the curriculum is not continuously developed to match their mental abilities. This result is matched with the result of both Alexander (2014); Alias and Salleh (2017) who have found that the incompatibility of curriculum considered the moderate priority level of difficulties that faced the teachers and stating that special needs schools need a curriculum that is flexible and not rigid.

The present study illustrated that more than half of the teachers faced difficulties due to difference in thinking capacity of the child and lack of interaction with the teacher were making the teaching process more difficult. These results may be due to the teachers make great effort to deliver the information to student with different thinking capacity. This result is similar with the result of Stokes, et al. (2016) who decided that the teachers often mentioned that a lack of different resources made it difficult for them to implement effective teaching. These difficulties included lack of understanding of the child, lack of teachers' time to work independently with the child and appropriately support the child.

Regarding to distribution of studied children according to their characteristics the present study revealed that the majority of intellectual handicapped children had moderate degree of handicapped. These findings are in accordance with Sappok et al, (2014); Shogren et al, (2017). All have agreed that the highest percentages degree of intellectual handicapped was found in mild and moderate degrees. This result was confirmed by American Psychiatric Association (2012) who reported that the 59.8\% of mental retarded children are in mild and moderate category.

The findings of the present study have revealed that the lowest percentages of handicapped children were profound degree. This may be due to the children with profound degree didn't attend to the intellectual schools and cannot take care of themselves. This result is similar to the findings of Shogren et al, (2017) who have reported that $18.9 \%$ of the children had profound degree. This found in a research under the title "Examining the Reliability and Validity of the Supports Intensity ScaleChildren's Version in Children with Autism and Intellectual Disability in U.S".

Concerning causes, the present study revealed that the majority of children were genetic factors. In contradiction with these findings Bhaskar \& Suresh, (2016) who found 
that $40 \%$ of intellectual handicapped causes were unknown. This found in a research titled "An empirical study on the prevalence and causes of Mental Retardation in Mangalore".

As regard the relation between the qualification of the teachers and the method of teaching, the study findings showed that there was no a statistically significant relation between the qualification of the teachers and methods of teaching (only with drawing methods). This result contradiction with Holzhauer, (2013) who illustrated that there was a statistically significant positive relationship between a special education teacher's level of professional development and using the different methods of teaching. This result present in a correlational study titled 'Special Education Teachers' Qualifications and Preferred Writing Instructional Strategy in University of Phoenix in United State of America".

Concerning relation between years of experiences of the teachers and the difficulties which exposed to the teachers. The results of the present study have indicated that there was no statistically significant relation between them. These results disagree with Essa \& Elzeftawy (2015) who have found that there was a statistically significant relation affecting the teachers' experience and knowledge problem. This present in the research of 'Teachers' Knowledge, Attitudes and Reported Strategies to Assess and Support the Students with Learning Difficulties in Egypt.

On the other hand the relation between school achievement of the intellectual handicapped child and the degree of mental disability. The present study shows that there were statistically significant relations between degree of mental disability and school achievement. These results are in agreement with Bostani, Nadri, and Nasab (2014) who have similarly reported that there were statistically significant relations between educational performance and mental health and some of its components. This present in a study of the relation between mental health and academic performance of students in Iran.

\section{CONCLUSION:}

In the light of the study findings, it can be concluded that: 
About more than half of teachers faced difficulties during teaching and the most difficulty was the frequent absence of the students. The majority of teachers developed the child skills in classrooms especially manual skills. Also, the majority of the children had mild degree of disability and partially dependent in daily living activities. The majority of child had a moderate success on school achievement and poor level of classrooms activities. Therefore the presence of intellectual handicapped child in the family made a financial overload and the child needed additional financial requirements without receiving any governmental supports.

\section{RECOMMENDATIONS:}

Based on the results of the present study, the following recommendations were suggested:

- Improvement the educational curriculum for handicapped children to be suitable for the intellectual level.

- Providing the school of mentally retarded children with well-trained team including physicians, nurses, teachers, psychologists, social workers, psychiatrists, speech therapists and Physiotherapists.

- Enhancing mental ability through small task of learning to improve level of dependence especially activity of daily living.

- Increasing the availability of personal computer having program for this children.

- Conduct researches about the needs of intellectual handicapped children.

-Enhance the role of school nurse toward mental children to improve their health status.

\section{REFERENCES:}

Ahmed, R.E. (2010). Nursing intervention protocol for nurses working with psychotic patients, unpublished Doctorate thesis. Psychiatric and Mental Health Nursing, Faculty of Nursing, Benha University.

Alexander, H. (2014). Challenges faced by teachers when teaching learners with developmental disability, unpublished Master thesis of philosophy in special needs. Education Department of Special Needs, Faculty of Educational Sciences University of OSLO.

Alias, A., \& Salleh, N. (2017). Analysis of problems faced by special education teacher in teaching multiple students. Journal of ICSAR, 1 (1), 60-67. 
American Association on Mental Retardation," AAMR", (2015). Intellectual disabilities: Definition and causes. (7th ed.). Williams and Wilkins.

American Psychiatric Association, (2012). Diagnostic and statistical manual of mental disorder (4th ed.) text revision. Washington.

Beck, A.J., \& Boulten, M.L. (2016). The public health nurse workforce in U S state and local health department 2012. Journal of Public Health Reports, 131 (1), 145152.

Bhaskar, B., \& Suresh, S. (2016). An empirical study on the prevalence and causes of mental retardation in Mangalore. Journal of Biomedical and Pharmaceutical Research, 5 (3), 58-61.

Bostani, M., Nadri, A., \& Nasab, A.R. (2014). A Study of the relation between mental health and academic performance of students of the Islamic Azad University Ahvaz Branch. Social and Behavioral Sciences, 116, $163-165$.

Boujut, E., Dean, A., Grouselle, A. \& Cappe, E. (2016). Comparative study of teachers in regular schools and teachers in specialized schools in France, working with students with an autism spectrum disorder: Stress, social support, coping strategies and burn out. Original Paper,46(9), 2874-2889.

Donna, R., Flavo, A. \& Ballard, K.A (2013). Psychiatric mental health nursing, clients with intellectual and development disabilities (2nd ed.). An Ascend Learning Company. United State of America.

Essa, H.A., \& Elzeftawy, A.M. (2015). Teachers' knowledge, attitudes and reported strategies to assess and support the students with learning difficulties. Journal of Nursing and Health Science, 4 (2), 79-92.

Hamdan, A., Anuar, M.K. \& Khan, A. (2016). Implementation of co-teaching approach in an inclusive classroom: Overview of the challenges, readiness, and role of special education teacher. Education Research Institute, Seoul National University, Seoul, Korea, 17 (8), 289-298. 
Holzhauer, K.E (2013): A correlational study of special education teachers' qualifications and preferred writing instructional strategy, unpublished Doctor thesis of Education in Curriculum and Instruction, University of Phoenix.

McKenzie, K., Milton, M., Smith, G., \& Ouellette-Kuntz, H. (2016). Systematic review of the prevalence and incidence of intellectual disabilities: current trends and issues. Current Developmental Disorders Reports, 3(2), 104-115.

Rady, F.M. (1999). Study of some of the variables related to mental exhaustion of teachers of special groups, unpublished Doctorate thesis, Psychology Department, Faculty of Education, Mansoura University.

Sappok, T., Budczies, J., Dziobek, I., Boltes, S., Dosen, A. \& Diefenbacher, A. (2014). The missing link: Delayed emotional development predicts challenging behavior in adults with intellectual disability. Original paper, 44, 786-800.

Shogren, K.A., Shaw, L.A., Wehmeyer, M.L., Thompson, J.R., Lang, K.M., Tasse, M.J. \& Schalock, R.L. (2017). The support needs of children with intellectual disability and autism: Implications for supports planning and subgroup classification. Journal Autism Dev Disorder. 40, 373- 384.

Stokes, M. A., Thomson, M., MacMillian, C., Pecora, L., Dymond, S.R. \& Donaldson, E. (2016). Principals' and teachers' reports of successful teaching strategies with children with high- functioning autism spectrum disorder. Canadian Journal of School Psychology, 1, (1), 1-17.

Vas, SH., Wilson, N., Falkmer, M., Sim, A., Scott, M., Cordier, R., \& Falkmer, T. (2015). Factors associated with primary school teachers' attitudes towards the inclusion of students with disabilities. Journal pone, 10 (2), 1-12.

Waziry, A. (2002). The effect educational program on improving self-care of mentally retarded children, unpublished Doctorate thesis, Pediatric Nursing, Faculty of Nursing, Alexandria University. 


\section{صعوبات التعليم والتطلم للمـدرسـين والأطـفــال المـعاقين ذهـــــاً بالفصول التعليمية فـي مسليـنـة المنـصـورة}

ا.د / إيناس حلمي الثاعر ـ.أ.د/ مها موسي محمد موسي _ـد. عفاف عبد الله محمد مسعد - م/هبه السعيد محمد السعيد الإمام.

أستاذ تمريض صـحسة المجتمع ـكلية الـتمـريض - جامعسة القاهرة - أستاذ مساعـد تمـريض صحة الأسرة والمهتمع ـكلـية التهريض - جامعة بورسعبيد - مدرس تمريض صحة الأسرة والمجتمع - كلبة التمريض - جامعة بورسعيل - بكالوريوس تـمريض - جامعة القاهرة (2006)

\section{الــــلاصـــة}

الإعاقة الذهنية مصطلح يستخدم عندما يكون لاى الثخص بعض القصور في الأداء العقلي وفي المهارات المختلفة مثل التواصل، انشطة الحياة اليومية و المهار ات الاجتماعية ـ الـــــف تقييم صعوبات التعليم و التعلم للمدرسين والأطفال ذوى الإعاقة الذهنية في الفصول التعليمية في مدينة المنصورة. نـوع الــدراسة دراسة وصفية توضيحية مكان الدراسة خمس مدارس فكرية بمدينة المنصورة. العينة عينة عشوائية من الطلاب (273) طالب و( 150) مدرس من المدارس السابقة. ادوات البحث الاداة الاولي تقبيم لبعض المتغيرات المرتبطة بالإنهاك النفسي لدى معلمي

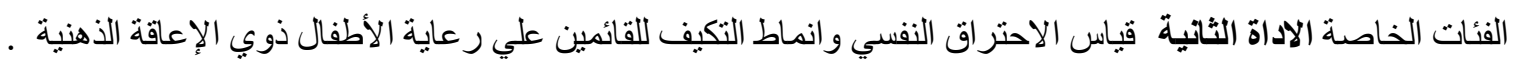
الهم التتانج 65.3 \% من الددرسين يو اجهون صعوبات اثناء عملية التدريس بسبب غياب الأطفال المتكرر، و 71.1 \%

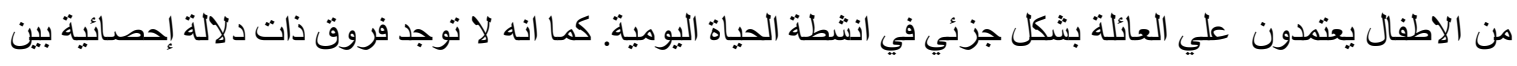
سنوات الخبرة لدي المدرسين والصعوبات التي تواجههم اثثاء الثرح. الخلاصة اكثر من نصف المدرسين يو اجهون صعوبات اثناء عملية التدريس، غالبية الاطفال لديها اعاقة من الدرجة الخفيفة. التوصيات تقديم دورات تدريبية اللمدرسين لتطوير معلوماتهم عن طرق التدريس المتبعة مع الأطفال و لمقدمي الرعاية لتحسين حالة ابنائهم الصحية .

الكلمات المرشدة: الاعـاقـة الذهنية ، صـوبـات التعليم والتعلم ، مدرسين الاطفال ذوي الإعاقة الذهنية ـ مدينة 